\title{
INTERRELATION BETWEEN EXERCISE HEART RATE, POST-RUN SYSTOLIC BLOOD PRESSURE, AND MYOCARDIAL STRUCTURE IN DISTANCE RUNNERS
}

\author{
Tomas Venckūnas, Birutė Mažutaitienė, Arvydas Stasiulis \\ Lithuanian Academy of Physical Education, Kaunas, Lithuania
}

Tomas Venckūnas. Doctor of Biomedical Science, Associate Professor at the Department of Applied Physiology and Sports Medicine at the Lithuanian Academy of Physical Education. Research interests - impact of endurance training on the structure and function of the heart.

\begin{abstract}
Endurance running is an exercise practiced by athletes in many sports. Being beneficial to health, it is also undertaken by a great number of non-athletic individuals. Rigorous endurance training frequently induces symmetric (i. e. both ventricular chamber dilation and wall thickening) myocardial hypertrophy, which is a physiological adaptation. Although distance running is a sport associated with haemodynamic volume rather than pressure overload, in addition to enlarged cardiac output, systolic arterial blood pressure also considerably increases during running. The extent of the cardiac hypertrophy was shown to be correlated with peak blood pressure measured during laboratory exercise. However, the predominant type of myocardial hypertrophy (the ratio between the myocardial wall thickness and chamber size) in endurance runners remains contradictory, and the majority of the responsible factors are still to be determined. The aim of this study was to determine possible correlations between post-run systolic blood pressure and myocardial hypertrophy in endurance runners.

Standard transthoracic two-dimensional M-mode echocardiography was performed in white adult male distance runners $(n=49)$ of national level within four weeks of treadmill testing, which was a non-continuous incremental exercise test employed for the determination of the heart rate as well as post-exertional systolic blood pressure response. Runners'training volume (evaluated as the average number of hours per week spent training averaged over the past four weeks) correlated $(p<0.05)$ positively with the left ventricular $(L V)$ wall thickness but not with the cavity size or LV mass ( $p>0.05$ ). Training volume also positively correlated with systolic blood pressure response to exercise $(p<0.05)$, but negatively with submaximal exercise heart rate $(p<0.01)$. Post-run systolic blood pressure correlated positively with LV wall thickness and LV concentricity (namely, the ratio between the myocardial wall thickness and chamber size) $(p<0.05)$, but no significant correlation of any of the LV size parameters with resting heart rate, blood pressure, or systolic blood pressure in 2 to 4 min during the recovery period was revealed. Submaximal and maximal heart rate correlated significantly and negatively with LV wall thickness, LV mass, and systolic blood pressure measured immediately after running $(p<0.05)$.

Training volume and post-run systolic blood pressure have been found to correlate positively with $L V$ wall thickness and concentricity in white adult male distance runners. Negative correlation of exercise heart rate has been found with the post-exercise systolic blood pressure, LV wall thickness, and LV mass.
\end{abstract}

Keywords: myocardial hypertrophy, pressure overload, echocardiography, athlete's heart.

\section{INTRODUCTION}

I n contrast to the majority of other mammals, humans are naturally equipped for endurance running (Bramble, Lieberman, 2004). Distance running is a classical endurance exercise practiced by athletes of many sport disciplines. It is also undertaken by many non-athletic individuals and has a positive impact on health. Regular endurance training sufficient in volume and in- tensity triggers 'symmetric' (i. e. both ventricular chamber dilation and wall thickening) myocardial hypertrophy, which is considered a purely physiological adaptation (De Castro et al., 2006).

Distance running is classified as a sport associated with haemodynamic volume rather than pressure overload (Mitchell et al., 2005). However, in addition to both increased heart rate and 
systolic volume, systolic blood pressure (SBP) also considerably increases during running, and large fluctuations of pulse pressure are observed, and the extent of the cardiac hypertrophy was shown to correlate with peak blood pressure measured during laboratory exercise (Palatini et al., 1989). The arterial pulse pressure response to exercise was shown to be one of the determinants of concentricity (i. e. more pronounced wall thickening rather than chamber dilation (Haykowsky et al., 2002)) of runners' myocardium (Kasikcioglu et al., 2005). While competitive distance runners in response to their training are believed to develop symmetrical (i. e. both cardiac dilation and wall thickening of similar degree) or even eccentric (Pluim et al., 2000) (i. e. more pronounced chamber dilation rather than wall thickening (Haykowsky et al., 2002)) physiological cardiac hypertrophy, the concentric myocardial hypertrophy has been reported in professional endurance athletes who practice running as a sizeable component of their training and competition (Karjalainen et al., 1997; Palazzuoli et al., 2002; Venckunas et al., 2006). Anyway, the predominant type of myocardial hypertrophy in endurance runners remains clearly contradictory, as many authors have reported more pronounced chamber dilation as compared with wall thickening in these athletes (Morganroth et al., 1975; D'Andrea et al., 2002; Nagashima et al., 2003). There is even less understanding of the mechanisms involved in and the factors responsible for the development of the structural adaptation due to athletic conditioning (Kasikcioglu et al., 2005).

As one of the most potent stimuli for cardiac hypertrophy is arterial blood pressure, we have hypothesized that running-triggered haemodynamic pressure overload, measured as post-run SBP, explains (is responsible for) a significant proportion of LV wall thickness. The aim of the study was to determine possible correlations between post-run SBP and myocardial hypertrophy in endurance runners.

\section{METHODS}

Sample. The permission to conduct the study was given by the Regional Bioethics Committee. Forty-nine adult (18 to 42 years of age) male runners of national level who had been training for competitive distances from $800 \mathrm{~m}$ to the marathon were included in the study after their informed consent had been obtained. All the athletes were Caucasian and in their active training season at the time of the examination. They completed questionnaires to report their age, training experience in years, and weekly training volume in hours, averaged over the past four weeks. Athletes disclaimed usage of any chemical preparations. Clinical and training characteristics of the subjects are presented in Table 1.

Treadmill testing. A progressive incremental non-continuous exercise test was performed on a motorized treadmill (H/p/Cosmos Mercury 4.0, Nussdorf-Traunstein, Germany). The runners did not train at least $16 \mathrm{~h}$ and did not have meals at least $2 \mathrm{~h}$ before the testing. All the subjects were familiar with treadmill running.

The test consisted of 4-min running bouts of increasing intensity interspaced with 4-min passive rest spans in a seated position. The initial speed was $60 \%$ of the subject's average running velocity achieved during his last 5000-m race. Then the speed was increased by $0.7 \mathrm{~km} / \mathrm{h}$ each bout. Subjects ran on the treadmill a sufficient number of times to increase the blood lactate concentration above the level of $4 \mathrm{mmol} \cdot \mathrm{L}^{-1}$. Blood samples from fingertips were analysed by an enzymatic membrane. After each running stage, the athletes dismounted from the treadmill and were seated immediately. Cuff SBP was measured within $20 \mathrm{~s}$, and also at 2 and 4 min of the recovery period, always by the same investigator. Values of SBP measured immediately after cessation of running were carefully analysed. Maximal and minimal SBP values, as well as the SBP value after the last running stage were obtained for each athlete. In addition, all the SBP values

\begin{tabular}{|c|c|c|c|c|c|c|c|c|c|c|}
\hline $\begin{array}{l}\text { Age, } \\
\text { years }\end{array}$ & $\begin{array}{l}\text { Height, } \\
\text { m }\end{array}$ & $\begin{array}{l}\text { Body } \\
\text { mass, } \\
\mathrm{kg}\end{array}$ & $\begin{array}{l}\mathrm{BMI}, \\
\mathrm{kg} \cdot \mathrm{m}^{-2}\end{array}$ & $\begin{array}{l}\text { BSA, } \\
\mathrm{m}^{2}\end{array}$ & $\begin{array}{l}\text { Systolic } \\
\text { BP, mmHg }\end{array}$ & $\begin{array}{l}\text { Diastolic } \\
\mathrm{BP}, \mathrm{mmHg}\end{array}$ & $\begin{array}{l}\text { Heart rate, } \\
\text { beats } \cdot \mathrm{min}^{-1}\end{array}$ & $\begin{array}{l}\text { Training } \\
\text { experience, } \\
\text { years }\end{array}$ & $\begin{array}{l}\text { Training vo- } \\
\text { lume, hours / } \\
\text { week }\end{array}$ & $\begin{array}{l}\text { Table } 1 \text {. Subjects' } \\
\text { clinical and trai- } \\
\text { ning characteris- } \\
\text { tics }\end{array}$ \\
\hline $\begin{array}{l}24.6 \\
(7.4)\end{array}$ & $\begin{array}{l}1.80 \\
(0.06)\end{array}$ & $\begin{array}{l}69.9 \\
(5.9)\end{array}$ & $\begin{array}{l}21.5 \\
(1.8)\end{array}$ & $\begin{array}{l}1.89 \\
(0.09)\end{array}$ & $\begin{array}{l}133.0 \\
(13.3)\end{array}$ & $73.0(10.2)$ & $56.6(9.7)$ & $9.8(7.3)$ & $8.1(3.3)$ & $\begin{array}{l}\text { body surface area; } \\
\text { BP - arterial blood } \\
\text { pressure. }\end{array}$ \\
\hline
\end{tabular}


measured immediately after cessation of running were averaged for each subject. The difference between resting and exercise SBP was calculated by subtracting the averaged post-exercise SBP by resting SBP. As regards the later recovery period blood pressure, only the subject's average SBP at 2 and 4 min (separately) was analysed. Heart rate (HR) was recorded continuously averaging each 5-s interval (HR monitor Polar Accurex-Plus, Kempele, Finland). Maximal HR was determined as the highest 10 -s interval value during the final stages of the treadmill test, and HR at the running speed of $15 \mathrm{~km} / \mathrm{h}$ was extrapolated from the recorded exercise HR.

Echocardiography. Standard two-dimensional M-mode echocardiography, using ultrasound sonographer AU3 Partner (Esaote Biomedica, Genoa, Italy) with $2.5-\mathrm{MHz}$ transducer, was performed within four weeks of treadmill testing, as described earlier (Venckunas et al., 2006). Internal LV diameter, interventricular septal (IVS) and LV posterior wall (PWT) thicknesses were measured at end-diastole as recommended by the American Society of Echocardiography. The same professional cardiologist took three measurements of each of the parameters, and the average was calculated. Left ventricular mass (in $g$ ) was calculated using the following equation:

$\mathrm{LV}_{\text {mass }}=0.8 \times\left\{1.04 \times\left((\mathrm{IVS}+\mathrm{LVED}+\mathrm{PWT})^{3}-(\mathrm{LVED})^{3}\right)\right\}+0.6$,

where IVS is interventricular septum thickness, PWT is left ventricular posterior wall thickness and LVEDd is left ventricular internal diameter (all at end-diastole, in $\mathrm{cm}$ ).
Echocardiographic indices relative to body size were obtained by dividing absolute values by the body surface area (BSA) value of the same index order, i. e. LV wall thicknesses and diameter were divided by square rooted BSA, and LV mass was divided by square rooted and then cubed BSA. Body surface area was calculated according to the following formula (Du Bois, Du Bois, 1916): $\operatorname{BSA}\left(\mathrm{m}^{2}\right)=[\text { stature }(\mathrm{cm})]^{0.725} \times[$ body mass $(\mathrm{kg})]$ $0.425 \times 0.007184$.

The relative wall thickness (RWT) was calculated by dividing the sum of end-diastolic interventricular septum and LV posterior wall thicknesses by LV end-diastolic diameter. Resting cuff blood pressure (both systolic and diastolic) and heart rate were measured after the echocardiographic examination.

Statistics. The Pearson's bivariate two-tailed test was used in calculating the correlation coefficients. Echocardiographic LV size indices correlated with the following independent variables: SBP, HR, and training parameters. The significance level was set at $p$ value of 0.05 . All the analyses were performed with the SPSS for Windows release 13.0.

\section{RESULTS}

Runners' training volume correlated positively with absolute and relative IVS, PWT, as well as RWT ( $\mathrm{r}$ from 0.283 to $0.368, \mathrm{p}<0.05$ ), but not LV cavity size, LV mass or LV mass index $(p>0.05)$. Training volume also positi-

\begin{tabular}{|c|c|c|c|c|c|c|c|c|}
\hline Table 2. Correlation of left ventri- & & IVS & IVSrel & PWT & PWTrel & RWT & LVM & LVMi \\
\hline $\begin{array}{l}\text { cular structure to systolic blood } \\
\text { pressure }(\mathrm{SBP}) \text { and heart rate (HR) } \\
\text { response to treadmill running. Signi- }\end{array}$ & SBPaver & $\begin{array}{l}0.282 \\
p=0.049\end{array}$ & & $\begin{array}{l}0.306 \\
p=0.032\end{array}$ & $\begin{array}{l}0.309 \\
p=0.031\end{array}$ & $\begin{array}{l}0.319 \\
p=0.025\end{array}$ & & \\
\hline $\begin{array}{l}\text { ents are presented } \\
\text { Note. IVS - interventricular septum thic- } \\
\text { kness; IVSrel - relative interventricular }\end{array}$ & SBP@15km / h & & & $\begin{array}{l}0.292 \\
p=0.047\end{array}$ & $\begin{array}{l}0.292 \\
p=0.047\end{array}$ & $\begin{array}{l}0.294 \\
p=0.045\end{array}$ & & \\
\hline $\begin{array}{l}\text { septum thickness; PWT - left ventricular } \\
\text { posterior wall thickness; PWTrel — relati- } \\
\text { ve left ventricular posterior wall thickness; }\end{array}$ & SBPmax & & & & $\begin{array}{l}0.293 \\
p=0.043\end{array}$ & $\begin{array}{l}0.348 \\
p=0.015\end{array}$ & & \\
\hline $\begin{array}{l}\text { RWT - relative wall thickness; LVM - } \\
\text { left ventricular mass; LVMi - left ven- } \\
\text { tricular mass index; SBPaver - averaged } \\
\text { systolic blood pressure immediately after }\end{array}$ & SBPlast & & & $\begin{array}{l}0.334 \\
p=0.043\end{array}$ & $\begin{array}{l}0.338 \\
p=0.041\end{array}$ & $\begin{array}{l}0.344 \\
p=0.037\end{array}$ & & \\
\hline $\begin{array}{l}\text { running; SBP@ } 15 \mathrm{~km} / \mathrm{h} \text { - systolic blo- } \\
\text { od pressure immediately after running at } \\
15 \mathrm{~km} / \mathrm{h} \text {; SBPmax — maximal recorded }\end{array}$ & SBPmin & & & $\begin{array}{l}0.301 \\
p=0.037\end{array}$ & $\begin{array}{l}0.302 \\
p=0.037\end{array}$ & & & \\
\hline $\begin{array}{l}\text { systolic blood pressure immediately after } \\
\text { running; SBPlast - systolic blood pres- } \\
\text { sure immediately after the last running } \\
\text { bout; SBPmin - the lowest recorded }\end{array}$ & HRmax & $\begin{array}{l}-0.361 \\
p=0.014\end{array}$ & $\begin{array}{l}-0.348 \\
p=0.018\end{array}$ & $\begin{array}{l}-0.433 \\
\mathrm{p}=0.003\end{array}$ & $\begin{array}{l}-0.423 \\
p=0.003\end{array}$ & & $\begin{array}{l}-0.476 \\
p=0.001\end{array}$ & $\begin{array}{l}-0.473 \\
p=0.001\end{array}$ \\
\hline $\begin{array}{l}\text { systolic blood pressure immediately after } \\
\text { running; HRmax - maximal heart rate; } \\
\text { HR@ } 15 \mathrm{~km} / \mathrm{h} \text { - heart rate immediately }\end{array}$ & HR@15km / h & $\begin{array}{l}-0.327 \\
p=0.022\end{array}$ & $\begin{array}{l}-0.292 \\
p=0.042\end{array}$ & $\begin{array}{l}-0.322 \\
p=0.024\end{array}$ & $\begin{array}{l}-0.290 \\
p=0.043\end{array}$ & & $\begin{array}{l}-0.429 \\
p=0.002\end{array}$ & $\begin{array}{l}-0.375 \\
p=0.008\end{array}$ \\
\hline
\end{tabular}


vely correlated with SBP response to exercise ( $\mathrm{r}$ from 0.41 to $0.48, \mathrm{p}<0.01$ ), as well as SBPaver and HRmax product $(\mathrm{r}=0.371, \mathrm{p}=0.011)$, but negatively with HR@15km / h $(\mathrm{r}=-0.422$, $\mathrm{p}=0.003$ ).

Significant $(p<0.05)$ correlation coefficients of echocardiographic LV hypertrophy parameters to SBP and HR response to running are presented in Table 2.

Absolute LV diastolic diameter, but not wall thickness or LV mass, showed positive correlation with BSA $(r=0.544, p=0.001)$, pulse pressure at rest $(r=0.339, p=0.018)$, and negative correlation with the difference between resting and exercise SBP $(-0.340, \mathrm{p}=0.017)$. The latter parameter also correlated with RWT $(0.329, \mathrm{p}=0.021)$. Pulse pressure at rest also correlated with relative LV diameter $(\mathrm{r}=0.331, \mathrm{p}=0.022)$ and LV mass $(r=0.309, p=0.033)$. However, no significant correlation of any of the LV size parameters with resting HR or blood pressure, or SBP in 2 to $4 \mathrm{~min}$ during the recovery period was observed.

Both HRmax and HR@15km/h correlated negatively with the parameters of absolute and relative LV hypertrophy (Table 2), as well as SBP measured immediately after running $(\mathrm{r} \approx-0.38$, all $\mathrm{p}<0.04)$.

\section{DISCUSSION}

The study has revealed a positive correlation of post-run systolic blood pressure with LV wall thickness and concentricity in distance runners. This could be explained by the ability of athlete's heart with thicker myocardial wall to contract more powerfully during treadmill testing. An alternative interpretation is that more concentric myocardium hypertrophy is due to higher pressure response to daily training. These mechanisms may complement each other. The study has also shown that submaximal and maximal heart rate correlated negatively with LV wall thickness, LV mass, and systolic blood pressure measured immediately after running.

Some echocardiographic characteristics were shown to be influenced by the sport undertaken (Barbier et al., 2006). Increased myocardial mass due to both cavity dilation and wall thickening is a usual finding in endurance runners (Pluim et al., 2000; Fagard, 2003). Professional distance runners, though for a long time they were believed to possess more pronounced LV chamber dilation than wall thickening (Morganroth et al., 1975), were also shown not to have considerably lower relative wall thickness as compared with athletes from many other sports (Fagard, 2003; Hoogsteen et al., 2004), and even to be similar in LV cavity diameter to sedentary controls at least in one study (Palazzuoli et al., 2002).

Several physiological factors including endocrine, pressure responses to exercise, as well as diastolic filling pattern influence structural cardiac adaptation to regular exercise. Dynamic exercises including running favour venous return (Crawford et al., 1985; Goldhammer et al., 1999; Sundstedt et al., 2004), diastolic filling and accompanying distension of ventricular myocardium (mechanical stimulus to cardiac myocytes). Training volume and the duration of the haemodynamic overload as well as shifts in the hormonal milieu are also important factors which determine the extent of structural cardiac adaptation, namely myocardial mass. The results of the present study suggest that the amount of endurance running performed has an influence on distance runners' LV wall thickness rather than chamber size. Longer mechanical stimulus of voluminous training, instead of triggering dilation of the chamber, seems to induce net cardiac protein synthesis (wall thickening) and in such a way 'compensates' for the lower pressure overload during running as compared to the values triggered by strength / power athletes endeavour (MacDougall et al., 1985). This could plausibly explain the absence of lower (relative) myocardial wall thickness in long distance runners as compared with strength athletes (Fagard, 2003).

Interestingly, runners' training volume was not only negatively associated with submaximal heart rate, but also positively correlated with SBP increase due to exercise. The latter correlation might be explained by the ability of a better trained myocardium to contract more powerfully, and by the lower concentration of vasodilative metabolites produced, which leads to higher peripheral resistance at the same absolute workload in a better trained endurance runner.

Blood pressure during exercise is another possible factor involved in the development of both the type and the extent of cardiac hypertrophy (Karjalainen et al., 1997; D’Andrea et al., 2002). It remains controversial whether the extent to which SBP increase to exercise is or is not related to cardiovascular risk (Tanaka et al., 1996; 
Campbell et al., 1999). In non-athletes, maximal exercise SBP correlated with SBP at rest (Bassett et al., 1998), which was not the case in our study of athletes.

In strength-trained athletes, peak laboratory cycling SBP correlated with LV wall thickness (D'Andrea et al., 2002). In ultra-endurance triathletes, LV mass correlated positively with blood pressure during 8-hour physical exercise (Douglas et al., 1986); in endurance athletes, with peak veloergometric blood pressure (Karjalainen et al., 1997); and in middle distance runners, with peak pulse pressure attained during laboratory treadmill testing (Kasikcioglu et al., 2005). As regards the latter observation, direct (invasive) measurements have revealed not only a marked elevation of the SBP during rowing (Clifford et al., 1994) and running (Palatini et al., 1989), but also large intra-arterial systolic and pulse pressure fluctuations not only during oar strokes in rowers (Clifford et al., 1994) but also due to foot strikes during running (Palatini et al., 1989): mean blood pressure changes little during running, both systolic and diastolic blood pressure fluctuate in synchrony, creating oscillations in radial artery pulse pressure of 20 to $200 \mathrm{mmHg}$ (Palatini et al., 1989), and only slightly smaller oscillations have been recorded in the aorta during running (Rowell et al., 1968). This response, called 'beat phenomenon', is due to a foot-ground contact-generated pulse wave, which counters and sums up with the pulse wave created by the myocardial systole (Palatini et al., 1989). Foot strike also impacts the heart, additionally perturbing the consecutive myocardial contractions (Palatini et al., 1989; Derrick et al., 1998). However, as it cannot be denied that pulse pressure during running (also) fluctuates due to pressure waves in the tissues around the blood vessels, it is possible that arterial pressure oscillations do not reflect the arterial transmural pressure (Palatini et al., 1989). In any case, during running the heart has to pump blood in the presence of increased both preload and afterload (Rowel et al., 1968; Palatini et al., 1989).

The implications of beat phenomenon are not clear, though they may be related to the redistribution of blood flow (Palatini et al., 1989). Pulse pressure during running, though related to running technique, is not a good proxy of stroke volume (Palatini et al., 1989). Foot strikes become stronger during fatigue (Hamill et al., 1995), and then 'beats' would emerge more clearly. It was proposed that such large fluctuations could provide additional stimulus for cardiac hypertrophy (Clifford et al., 1994). However, we did not monitor blood pressure during actual running, and beats disappear on the discontinuation of running, when blood pressure was actually measured in our study.

\section{CONCLUSIONS}

Runners' training volume and systolic blood pressure in response to treadmill running have been disclosed to correlate positively with myocardial wall thickness and concentricity of left ventricular hypertrophy in white young adult male distance runners. Both maximal and submaximal exercise heart rate has been found to correlate negatively with post-exercise systolic blood pressure, left ventricular wall thickness, and left ventricular mass.

\section{REFERENCES}

D’Andrea, A., Limongelli, G., Caso, P. et al. (2002). Association between left ventricular structure and cardiac performance during effort in two morphological forms of athlete's heart. International Journal of Cardiology, 86, $177-184$.

Barbier, J., Ville, N., Kervio, G., Walther, G., Carre, F. (2006). Sports-specific features of athlete's heart and their relation to echocardiographic parameters. Herz, 31, $531-543$.

Bassett, D. R. Jr., Duey, W. J., Walker, A. J. et al. (1998). Exaggerated blood pressure response to exercise: Impor- tance of resting blood pressure. Clinical Physiology, 18, 457-462.

Bramble, D. M., Lieberman, D. E. (2004). Endurance running and the evolution of Homo. Nature, 432, 345-352.

Campbell, L., Marwick, T. H., Pashkow, F. J., Snader, C. E., Lauer, M. S. (1999). Usefulness of an exaggerated systolic blood pressure response to exercise in predicting myocardial perfusion defects in known or suspected coronary artery disease. The American Journal of Cardiology, 84, 1304-1310. 
De Castro, S., Pelliccia, A., Caselli, S. et al. (2006). Remodelling of the left ventricle in athlete's heart: a three dimensional echocardiographic and magnetic resonance imaging study. Heart, 92, 975-976.

Clifford, P. S., Hanel, B., Secher, N. H. (1994). Arterial blood pressure response to rowing. Medicine and Science in Sports and Exercise, 26, 715-719.

Crawford, M. H., Petru, M. A., Rabinowitz, C. (1985). Effect of isotonic exercise training on left ventricular volume during upright exercise. Circulation, 72, 1237-1243.

Derrick, T. R., Hamill, J., Caldwell, G. E. (1998). Energy absorption of impacts during running at various stride lengths. Medicine and Science in Sports and Exercise, $30,128-135$.

Douglas, P. S., O’Toole, M. L., Hiller, W. D., Reichek, N. (1986). Left ventricular structure and function by echocardiography in ultraendurance athletes. American Journal of Cardiology, 58, 805-809.

Fagard, R. (2003). Athlete's heart. Heart, 89, 14551461.

Goldhammer, E., Mesnick, N., Abonader, E. G., Sagiv, M. (1999). Dilated inferior vena cava: a common echocardiographic finding in highly trained elite athletes. Journal of American Society of Echocardiography, 12, 988-993.

Hamill, J., Derrick, T. J., Holt, K. G. (1995). Shock attenuation and stride frequency during running. Human Movement Science, 14, 45-60.

Haykowsky, M. J., Dressendorfer, R., Taylor, D., Mandic, S., Humen, D. (2002). Resistance training and cardiac hypertrophy: Unravelling the training effect. Sports $\mathrm{Me}$ dicine, 32, 837-849.

Hoogsteen, J., Hoogeveen, A., Schaffers, H. et al. (2004). Myocardial adaptation in different endurance sports: an echocardiographic study. The International Journal of Cardiovascular Imaging, 20, 19-26.

Karjalainen, J., Mantysaari, M., Viitasalo, M., Kujala, U. (1997). Left ventricular mass, geometry, and filling in endurance athletes: Association with exercise blood pressure. Journal of Applied Physiology, 82, 531-537.

Kasikcioglu, E., Oflaz, H., Akhan, H., Kayserilioglu, A., Umman, S. (2005). Peak pulse pressure during exercise and left ventricular hypertrophy in athletes. The Anatolian Journal of Cardiology, 5, 64-65.

MacDougall, J. D., Tuxen, D., Sale, D. G., Moroz, J. R.,
Sutton, J. R. (1985) Arterial blood pressure response to heavy resistance exercise. Journal of Applied Physiology, $85,785-790$.

Mitchell, J. H., Haskell, W., Snell, P., Van Camp, S. P. (2005). Task Force 8: Classification of sports. Journal of the American College of Cardiology, 45, 1364-1367.

Morganroth, J., Maron, B. J., Henry, W. L., Epstein, S. E. (1975). Comparative left ventricular dimensions in trained athletes. Annals of Internal Medicine, 82, 521-524.

Nagashima, J., Musha, H., Takada, H., Murayama, M. (2003). New upper limit of physiologic cardiac hypertrophy in Japanese participants in the $100-\mathrm{km}$ ultramarathon. Journal of the American College of Cardiology, 42, 1617-1623.

Palatini, P., Mos, L., Mormino, P. et al. (1989). Blood pressure changes during running in humans: The "beat" phenomenon. Journal of Applied Physiology, 67, 52-59.

Palazzuoli, A., Puccetti, L., Pastorelli, M. et al. (2002). Transmitral and pulmonary venous flow study in elite male runners and young adults. International Journal of Cardiology, 84, 47-51.

Pluim, B. M., Zwinderman, A. H., van der Laarse, A., van der Wall, E. E. (2000). The athlete's heart. A metaanalysis of cardiac structure and function. Circulation, 101, 336-344.

Rowell, L. B., Brengelmann, G. L., Blackmon, J. R., Bruce, R. A., Murrey, J. A. (1968). Disparities between aortic and peripheral pulse pressures induced by upright exercise and vasomotor changes in man. Circulation, 37, $954-960$

Sundstedt, M., Hedberg, P., Jonason, T., Ringqvist, I., Brodin, L. A., Henriksen, E. (2004). Left ventricular volumes during exercise in endurance athletes assessed by contrast echocardiography. Acta Physiologica Scandinavica, 182, 45-51.

Tanaka, H., Bassett, D. R. Jr., Turner, M. J. (1996). Exaggerated blood pressure response to maximal exercise in endurance-trained individuals. American Journal of Hypertension, 11, 1099-1103.

Venckunas, T., Stasiulis, A. Raugaliene, R. (2006). Concentric myocardial hypertrophy after one-year of increased training volume in experienced distance runners. British Journal of Sports Medicine, 40, 706-709. 


\title{
BE்GIKUৃ SISTOLINIO ARTERINIO KRAUJOSPŪDŽIO PO KRŪVIO, ŠIRDIES SUSITRAUKIMŲ DAŽNIO KRŪVIO METU IR MIOKARDO STRUKTŪROS TARPUSAVIO SĄSAJA
}

\author{
Tomas Venckūnas, Birutė Mažutaitienė, Arvydas Stasiulis \\ Lietuvos kūno kultūros akademija, Kaunas, Lietuva
}

\section{SANTRAUKA}

Ištvermès lavinamasis bėgimas taikomas rengiant daugelio sporto šakų atletus. Jis yra viena iš svarbiausių bendrosios populiacijos sveikatinimo priemonių. Intensyvios ir reguliarios ištvermès lavinamojo bėgimo pratybos dažnai sukelia simetrišką fiziologinio pobūdžio miokardo hipertrofiją, t. y. širdies skilvelio sienelès sustorejjimą kartu su jo ertmės padidejjimu. Nors ilgujų nuotolių bėgimas daugiausia siejamas su padidejjusia širdies ir kraujagyslių sistemos apkrova, ištvermès lavinamojo bėgimo metu be padidejjusio minutinio širdies tūrio smarkiai išauga sistolinis arterinis kraujospūdis. Miokardo hipertrofijos dydis koreliuoja su didžiausiu laboratorinio testo metu pasiekiamu kraujospūdžiu, tačiau ilgujų nuotolių bėgikų miokardo hipertrofijos tyrimų rezultatai skiriasi. Lieka neaišku, nuo ko tai daugiausia priklauso. Tyrimo tikslas — nustatyti galimą ryši tarp sistolinio arterinio kraujospūdžio, išmatuoto po bėgimo testo, ir bejgiku miokardo hipertrofijos dydžio.

Standartinė transtorakalinė echokardiografija atlikta ištvermę lavinantiems (vidutinių ir ilgujų nuotolių) bėgikams $(n=49)$ likus ne daugiau kaip mėnesiui iki testavimo laboratorijoje bėgtakiu — intervalinio nuolat sunkinamo testo metu buvo išmatuotas širdies susitraukimų dažnis bėgant ir sistolinis kraujospūdis po bègimo.

Bègikų treniravimosi apimtis (vidutiniškai valandomis per savaitę) koreliavo $(\mathrm{p}<0,05)$ su kairiojo širdies skilvelio (KS) sienos storio rodikliais, tačiau nebuvo susijusi su KS vidiniu skersmeniu ar mase $(\mathrm{p}>0,05)$. Treniravimosi apimtis taip pat teigiamai koreliavo su sistolinio kraujospūdžio reakcija ị bègimo krūvị, tačiau neigiamai - su submaksimaliu širdies susitraukimu dažniu bėgimo testo metu $(p<0,01)$. Po bėgimo išmatuotas sistolinis kraujospūdis tiesiogiai koreliavo su KS sienos storio rodikliais ir KS koncentriškumu $(p>0,05)$, tačiau reikšmingos koreliacijos tarp KS struktūros dydžių ir ramybės širdies susitraukimų dažnio, ramybės kraujospūdžio ar sistolinio kraujospūdžio antrą — ketvirtą atsigavimo minutę nebuvo. Bègimo metu pasiekto submaksimalaus ir maksimalaus širdies susitraukimų dažnio rodikliai neigiamai koreliavo su KS sienos storio duomenimis, KS mase ir sistoliniu kraujospūdžiu, išmatuotu tuoj pat po bėgimo $(\mathrm{p}<0,05)$.

Taigi treniravimosi apimtis ir sistolinis kraujospūdis po bėgimo teigiamai koreliuoja su jaunu bègiku kairiojo širdies skilvelio koncentriškumo ir sienos storio rodikliais. Tarp širdies susitraukimų dažnio bėgimo metu ir sistolinio kraujospūdžio bei kairiojo širdies skilvelio masès ir sienos storio rodiklių nustatyta neigiama koreliacija.

Raktažodžiai: miokardo hipertrofija, perkrova slègiu, echokardiografija, sportininko širdis.

Gauta 2007 m. kovo 22 d.

Received on March 22, 2007

Priimta 2007 m. rugsejjo 19 d.

Accepted on September 19, 2007
Tomas Venckūnas

Lithuanian Academy of Physical Education

(Lietuvos kūno kultūros akademija)

Sporto str. 6, LT-44221 Kaunas

Lithuania (Lietuva)

Tel +37061426621

E-mail t.venckunas@gmail.com 